\title{
Riktig bruk av medikamenter
}

Høy alder og svekket syn kan komplisere enkle ting, noe jeg forleden fikk oppleve.

I likhet med mange andre i 90-årene, har jeg fått foreskrevet medikamenter til daglig bruk. På grunn av svekket syn, kan det være vanskelig å holde orden på medikasjonen. Da er det godt å ha fagfolk i nærheten som jeg kan benytte meg av.

Forleden fant jeg en håndfull løse tabletter på nattbordet. Det var uklart for meg hva disse skulle brukes til. Jeg antok at det måtte være sovetabletter, så jeg prøvde dem ut et par netter. De fungerte helt utmerket og jeg sov bedre enn på lenge. Men etter nok et par netter uten blund på øynene, ble jeg litt i tvil om disse virkelig var sedativer.
Hva kunne det da være? Når jeg kjente etter, så følte jeg meg ikke helt vel. Kunne det være blodtrykksmedisiner? Dette måtte klargjøres. Jeg ville oppsøke apoteket for å høre om de kunne gjenkjenne tablettene og deres indikasjonsområde.

Jeg kledde på meg frakken og la i vei til nærmeste apotek. Det var mye folk på apoteket, men jeg stilte meg pent $\mathrm{i}$ køen, selv om det var noe av det verste jeg visste. Det gikk nær en halv time før jeg fikk presentert mitt problem for farmasøyten. Da var jeg blitt lett irritabel, så jeg presenterte meg høylydt som doktor Engeset og viste ham tablettene og spurte om han kunne si hva disse skulle brukes mot da jeg ikke hadde kjent noe virkning. «Nei, doktor Engeset,» svarte han vennlig, «disse virker nok ikke gjennom magen. De skal du ha i ørene for å få virkning. Det er batterier til høreapparatet.»

Da jeg tuslet hjemover, tenkte jeg med gru på hvor livredde folk som har fått medisiner av meg ville bli om de hører denne historien. Jeg har derfor valgt å tie om det hele.

\section{Arnfinn Engeset \\ Oslo}

Mottatt 18.11. 2010 og godkjent 2.12. 2010. Medisinsk redaktør Erlend Hem. 